る. 性能的に恃上巾 $10 \mathrm{~mm}$ のもので従来 B 型の伝達馬力 を有しベルト速度も従来品の $25 \mathrm{~m} / \mathrm{sec}$ が限度に比べ $50 \mathrm{~m}$ / sec まで走行でき，かつ耐久性む 5 万キ口以上である。 本邦においても最近これらの高性能ファンベルトが採用 されはじめているが自動車産業高速道路の発展と相まっ て普及して行くものと考えられる。

\section{3. ファンベルトの疲労}

フォンベルトの疲労の因子としては大体次のごときも のがある。

(i) 心体 屈曲繰返しによる疲労 (ii) 外被 摩耗および土砂，水による劣化

(iii) ゴム 屈曲による引張り圧縮変形の絽返し，側 压による圧縮変形の絽返し，変形の絽返 しによる発熱

（iv）発熱および変形の絽返しによる各材料相互間の 接着力の低下

(v) スリップによる異常摩耗扔よび発熱

通常の破壊は変形疲労拉よび発熱のため各材料相互間

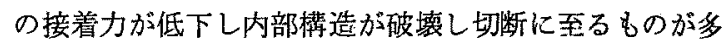
い.したがって材料，接着技術の耐熱性，耐屈曲疲労性 に負うところが大きい。

\title{
ウエザーストリップ
}

\section{1. ま えがき}

スポンジゴム製のウェザーストリップに限定して述べ ることにする。

スポンジゴムはその気泡構造から「独立気泡スポンジ ゴム」と「連続気泡スポンジゴム」の 2 種類に大別する ことができる、製造法はそれぞれ異なっており，前者は 成形型に充満させたゴム材料を加熱させて発泡剂を分解 し，外王を除去する際に分解時のガス圧で膨張させるも のである．彷って製品形状としてはシートのような単純 なものに限られる，後者は成形型の容積に30〜50\%の配 合ゴムを充てんし加熱によって発泡剂を分解し，製造時 に使用される金型形状に沿って膨張させるので，ある程 度複雑な製品に灾用することが可能である，一般にウェ ザーストリップ類としては後者の連続気泡スポンジゴム が使用される。

ウェザーストリップとしては次のことが满足しなけれ ばならない。

1）車体に緊密に適応した形状であること。

2）車外からの水が入らないこと。すなわち雨湡れの ないこと。

3）耐久性がよいこと，すなわち老化に強く，機械的 緥り返し荷重に強く変形しにくいこと.

4)外観が良いこと。

* 名古屋ゴム株式会社

\section{杉田 清* 小林 ${ }^{*}$ 殖}

以下材質，形状につき述へることにする。

$$
\text { 2. 材質 }
$$

スポンジゴムは主として天然ゴムが使用されている が，必要に応じて各種の合成ゴムと混合あるい柱單独に 态用される．ウェザーストリップ類に使用する場合は前 記の要求を满足しなければならないので，とくに柔軟性 ，および発弾性および承久ひずみなどの性能が要望され るので，一般に天然ゴムが使われる．天然ゴムとしてス モークシートを原料として使用される場合は耐候，䩂老 化性を考慮して笠品表面に合成ゴム（ネオプレンなど） の被膜を応用している．天然ゴムとしてラテックスを原 料とする場合仕表面に柔軟で耐候性のある塗料（ウレタ ン系ネオプレン系，ハイパロン系など）をコーティング あるいはディッピングして欠点を補っている。

\section{1 材質規格}

スポンジ規格としては一般に次のものが採用されてい 乃.

スポンジゴム SAE 18R（詳細は ASTM D 1056-59T) 外層被膜 SAE 10R R410

\section{3. 製 品 形 状}

ウェザーストリップの形状は各車体のデザインが異な るため種々雑多のものが応用されているが，形状を決定 するに当っては使用条件を満足すべきことはもちろんで 
あるが、コストおよび生産能力に大きく影響することを 考虑して極力単純な形状にすることが必要である。

\section{1 寸法公差}

スポンジゴム製品の寸法公差はVDI 2005 の 3 級公差 がー般に適用される。

表 1 寸法公差 VDI*1 2005

\begin{tabular}{|c|c|c|c|}
\hline 製 品 寸 法 & 1 級 & 2 級 & 3 級 \\
\hline $0 \sim 3 \mathrm{~mm}$ & $\pm 0.2 \mathrm{~mm}$ & $\pm 0.3 \mathrm{~m} \mathrm{~m}$ & $\pm 0.4 \mathrm{~mm}$ \\
\hline $3 \sim 6$ & \pm 0.2 & \pm 0.4 & \pm 0.5 \\
\hline $6 \sim 10$ & \pm 0.3 & \pm 0.5 & \pm 0.6 \\
\hline $10 \sim 18$ & \pm 0.3 & \pm 0.6 & \pm 0.8 \\
\hline $18 \sim 30$ & \pm 0.4 & \pm 0.8 & \pm 1.0 \\
\hline $30 \sim 50$ & \pm 0.5 & \pm 1.0 & \pm 1.5 \\
\hline $50 \sim 80$ & \pm 0.6 & \pm 1.2 & \pm 2.0 \\
\hline $80 \sim 120$ & \pm 0.7 & \pm 1.4 & \pm 2.5 \\
\hline $120 \sim 180$ & \pm 0.8 & \pm 1.6 & \pm 3.0 \\
\hline $180 \sim 250$ & \pm 1.0 & \pm 2.0 & \pm 4.0 \\
\hline $250 \sim 315$ & \pm 1.2 & \pm 2.5 & \pm 5.0 \\
\hline $315 \sim 400$ & \pm 1.5 & \pm 3.0 & \pm 6.0 \\
\hline $400 \sim 500$ & \pm 1.8 & \pm 3.5 & \pm 7.0 \\
\hline 500 以上 & $\pm 0.4 \%$ & $\pm 0.8 \%$ & $\pm 1.5 \%$ \\
\hline
\end{tabular}

*1 VDI は Verein Deutsche Ingenieur（ドイッ工業 協会規格）

長さの寸法公差の中，表 1 とは別に当事閒で用途に応 して適宜協定の上決定している。

\section{2 形状の決定}

スポンジゴム製のウェザーストリップの形状を決定す るに当っては下記のような一般的注意事項があげられ る。

1) パーティングライン(型割点)を少なくするような 形状にすること，被膜を適用する必要があるので， どうしてもパーティングが多くなりがちなので不必 要な個所は事前検討を充分化行なって使用をできる だけ避けるようにしなけれでならない，車体一の接 着面比ついて接着強度を增すため比被膜をつけな いのが普通である。

2）製品形状によって圧縮時の荷重（がたさ）が異な るゅえ，製品の組付状態を考虑すること。

3）合成ゴムスポンジは天然ゴムのスポンジに比較し て成形加工が困難であるから，形状の単純化にとく 汇留意すべきである。

4）独立気泡スポンジゴムは彷来の方法ではシート以 外のものは困難であるから, 複雑な形状のものは連 続気泡のむのが好むしい. しかし最近開発された連 統成形法によるものが現われるようになったので，
独立気泡構造のものも採用される気運になりつつあ る.

しかし注意しなければならないことは压縮歪率に 抒いて SAE 規格に準执した試驗法の結果，独立気 泡のものは連続気泡のものの $5 \sim 6$ 倍の黄い值を示 すことである。

\section{3 性能}

1）压縮荷重の設定に当っては前記 SAE 18R の規格 を参考にしてかたさなどを決める，一般に压縮荷重 試験と压縮永久ひずみ試駗とをもって規制する，ス ポンジゴム製品は形状によって圧縮荷重值が異なる ため，圧縮荷重のセットは製品を取付けた状態にお いて実施する．また圧縮荷重の設定方法はテストピ ースとして製品より一定の長さを切取ったものを対 称とし，25\%王縮した場合の荷重をもって定める.

2）製品の老化性については ASTM 1149 によりオ ゾンき裂の程度を試験する．当事者閒の協定でオソ ン濃度，き裂発生時間を決めているが，オゾン涇度 として一般に応用されているのは $25 \sim 50 \times 10^{-8} \mathrm{ppm}$ である。

3）耐水性はウェザーストリップの要求性能として重 要なる位置を占めているが，JIS K 6380 に準拠し て試驗される，吸水性が多く，気泡の中に含まれる と寒冷地において凍結するために外部よりの衙拏に より気泡が破塓されて機能が阻害される危険があ る。

\section{4 形状の一例}
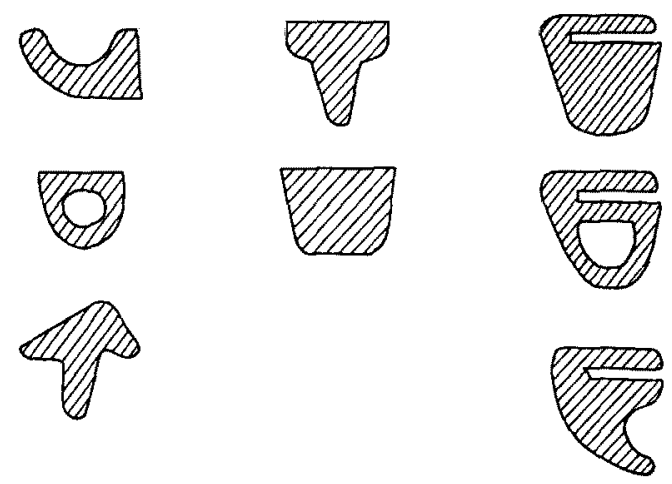

\section{参考文献}

1) SAE Handbook 1963

2) ASTM Standards on Rubber Products 1962

3）自動車用ゴム・プラスチックス製品特集号：ゴム 協，33，10号 (1960)

4) VDI-Richtlinien 2005: Gestaltung und Anwendung von Gummi-Teilen 